\section{A responsabilidade de proteger: uma releitura da soberania a partir das premissas da diversidade cultural e da racionalidade social, no contexto da ideia da autodeterminação do indivíduo em matéria de direitos humanos*}

\section{The responsibility to protect:}

a rereading on sovereignty from premisses of cultural diversity and social rationality within the context of ideas of individual self-determination on the matter of human being rights

\section{Resumo}

Este artigo analisa a dinâmica do instituto da Responsabilidade de Proteger sob a ótica da diversidade cultural e da racionalidade dos direitos fundamentais, a partir da releitura da ideia de soberania como autodeterminação do indivíduo em matéria de direitos humanos. Por meio da pesquisa dogmática e instrumental, e da técnica bibliográfica, verificou-se que a Responsabilidade de Proteger alcança um patamar de valores constitucionais na medida em que a soberania, em seu perfil clássico, sofre uma releitura a partir dos direitos humanos, tendo como ênfase o papel dos direitos fundamentais e sua racionalidade no respeito à diversidade cultural. O tema da segurança nas relações internacionais e a responsabilidade de prevenir, de reparar e de reagir ressaltam a evolução da discussão, a ponto de se indagar se os caminhos e as premissas do Estado soberano devem permanecer incólumes diante das afrontas cometidas ao valor fundamental da dignidade da pessoa humana. Com a responsabilidade de proteger, novos padrões de adoção dos direitos humanos - como a busca da efetividade - são reconhecidos pelos Estados que pertencem à ONU, com a possibilidade de efeito irradiante dos direitos humanos na conduta dos Estados no plano das relações internacionais. A reconstrução da paz torna-se a pauta global dos países membros da ONU, que envolve um diálogo transdisciplinar, não apenas aqueles que estão imersos no combate e os refugiados e os repatriados, mas também outras nações e outras culturas, inclusive os ingressos na formulação do terror, de modo que a soberania revela-se como a capacidade do Estado em formular a paz, com a responsabilidade de prevenir, reagir e reconstruir a vida dos povos, permitindo que, gradualmente, os direitos humanos ganhem corpo na racionalidade social e no multiculturalismo, promovendo a autodeterminação do indivíduo em matéria de direitos humanos, capaz de alcançar aquilo que Kant delimitou como a paz perpétua entre os povos: o respeito à diversidade e à essência do conteúdo essencial dos direitos e garantias das pessoas concernentes em harmonia com a estrutura institucional do Estado.

Palavras-chave: Responsabilidade de proteger. Racionalidade dos direitos fundamentais e diversidade cultural. Soberania como autodeterminação do indivíduo em matéria de direitos humanos. 


\section{Abstract}

This article analyzes the dynamics involved in the Responsibility to Protect under the viewpoint of cultural diversity and rationality of basic rights, taking into consideration the rereading of the idea of sovereignty as a self-determination of the individual regarding human rights. Through dogmatic and instrumental research and bibliographic technique, it has been verified that the Responsibility to Protect can reach a level of constitutional value, as sovereignty, in its classic profile, is reinterpreted through Human Rights with an emphasis on the role of fundamental rights and its rationality concerning cultural diversity. The issue of security in international relations and responsibility to prevent, react and repair highlights the evolution of the discussion up to the point one should ask whether the paths and premises of the sovereign State must remain unscathed in the face of outrages committed to the fundamental value of dignity of the human person. With the responsibility to protect, new standards of adoption of human rights - as the search for effectiveness - are recognized by the States which belong to the UN, with the possibility of radiating effects of Human Rights on the conduct of the States in international relations. The reconstruction of peace has become the global agenda of UN member countries, what involves a transdisciplinary dialogue, among not just those who are immersed in combat, refugees and returnees, but also other nations and other cultures, including the ones which sponsor terrorism, so that sovereignty is revealed as the State's ability to formulate peace with the responsibility to prevent, react and rebuild the lives of people, gradually allowing Human Rights to gain a solid body in rationality and social multiculturalism, promoting self-determination of individual Human Rights, being able to achieve what Kant delimited as the perpetual peace among the people, respect for diversity and the essence of the essential rights and guarantees of persons concerned in accordance with the institutional structure of the State.

Keywords: Responsibility to Protect. Rationality of the fundamental rights and cultural diversity. Sovereignty as a self-determination of the individual regarding Human Rights.

\section{Considerações Iniciais}

O conceito de soberania emerge das discussões dos Estados Nacionais e passa da capacidade do Estado em impor seu respeito à capacidade dos Estados Nacionais em construir um cenário de paz e bem-estar social.

Essa premissa surge no momento em que, no plano internacional, os Estados buscam recompor suas alianças e firmar um compromisso de negociação amigável no campo do comércio e nas relações institucionais.

Nesse contexto, o distúrbio na conformação da vontade dos Estados em levar a cabo suas ambições de prosperidade e paz e de impor os seus valores constitutivos de sua sociedade e de seu contrato social esbarra na diversidade cultural espalhada pelos diversos regimes normativos pertencentes a todos os espaços globalmente reconhecidos.

A medida impõe nova conformação na qual os Estados Nacionais passam a ter que buscar a paz não apenas pela reação, mas pela prevenção. Surge, em outra medida, a ascensão do conceito de responsabilidade de proteger, em que as Nações Unidas, com o auxílio dos Estados, buscam evitar que as barbáries acometam as sociedades de todo o mundo.

Para enfrentar essa perspectiva, é necessário que se questione: a soberania está sendo reformulada? Qual o novo contexto da soberania no Direito Internacional?

Como premissas de análise, tem-se como hipótese saber se a soberania pode ser contextualizada como a autodeterminação do indivíduo em matéria de direitos humanos e, em perspectiva, saber se os direitos humanos e os direitos fundamentais podem ser lidos em uma metodologia que prima pela racionalidade social e pelo respeito às diversas etnias culturais conformadoras das Nações Unidas.

Convida-se, nesse contexto, o intérprete a dialogar acerca do tema e a colocar em perspectiva como evoluir o conceito e o problema de pesquisa ora proposto.

\section{0 "sujeito" em sua conformação dinâmica: a releitura da soberania como autodetermina- ção do indivíduo em matéria de direitos hu- manos}

A crise nas instituições governamentais, cujos países compartilham matrizes constitucionais comuns, tem criado um movimento de reconhecimento do papel do indivíduo que se lastreia no âmbito interno e no âmbito 
internacional, guiado pela premissa antropológico-cultural da dignidade da pessoa humana. Com efeito, isso conduz a abertura de maior participação do sujeito ${ }^{2}$ no processo de tomada de decisão, que enseja um reflexo na proteção dos direitos fundamentais, cuja manifestação no âmbito internacional se realiza na busca da proteção dos direitos humanos.

A partir do reconhecimento do sujeito, é preciso "emancipá-lo" a fim de possibilitar a sua participação no processo de tomada de decisão. Isso se inicia com a criação de procedimentos no direito constitucional interno de alguns Estados Constitucionais, em que a estrutura e o conteúdo desses procedimentos podem ser levados a outros Estados Constitucionais ou a outras culturas.

A fim de compartilhar instrumentos jurídicos entre as diversas culturas, na busca por um "direito comum de cooperação", o Estado Constitucional Cooperativo constitui o modelo teórico proposto por Peter Häberle para desenvolver seu pensamento em torno da proposta de uma teoria da Constituição como ciência da cultura. Enquanto modelo teórico - que se fundamenta na lógica da cooperação -, busca aperfeiçoar os Estados de Direito existentes com elementos que possibilitem uma aproximação entre os povos por meio do elemento cultural.

O Estado Constitucional Cooperativo se baseia, em um primeiro momento, em dois motivos e pressupostos: (i) o sociológico-econômico e (ii) o ideal-moral. A partir desse modelo teórico, Häberle propõe uma releitura do Estado Nacional e dos seus elementos: ao invés de se fechar em seu sistema jurídico, o Estado deve ser aberto, plural e em busca do diálogo. Assim, conta com a existência de "Estados Constitucionais", que leem o sistema jurídico à luz de "valores constitucionais" com a existência de textos constitucionais que determinam a aproximação entre os países, cuja "vontade de Constituição" é exercida, muitas vezes, pela cooperação econômica. Logo, o Estado Constitucional Cooperativo se realiza por meio das interrelações econômicas e as efetiva conjuntamente com sua evolução, pois o conhecimento das formas econômicas de cooperação e sua aplicação em conceitos, processos e

2 Ou dependendo da visão dinâmica, "atores", que se classificam em públicos ou privados - cívicos, como os indivíduos, as associações, os sindicatos, as igrejas, as ONGs; e econômicos, como as empresas e suas respectivas entidades de classe. competências jurídicas adequadas exigem a interligação com métodos e objeto da Teoria Geral do Estado. ${ }^{3}$

Por outro lado, os pressupostos ideais-morais do Estado Constitucional Cooperativo - que serão utilizados e desenvolvidos na dissertação - apenas podem ser apontados. São obtidos pela construção dos direitos fundamentais e dos direitos humanos no âmbito da sociedade aberta. Por essa razão, Häberle afirma que a "sociedade aberta" apenas adquire o predicado "aberta" quando também for uma sociedade aberta internacionalmente. Os direitos fundamentais e os direitos humanos remetem o Estado e seus cidadãos ao "outro", ao chamado "estrangeiro", isto é, a outros Estados com suas sociedades ou cidadãos estrangeiros. O Estado Constitucional Cooperativo vive de necessidades de cooperação no plano econômico, social e humanitário, bem como - em consonância com a premissa antropológica da dignidade da pessoa humana - sustenta-se da consciência e da cooperação, como também da internacionalização da sociedade, da rede de dados, da opinião pública mundial, da política e de legitimação externas. ${ }^{4}$

Portanto, esse modelo teórico necessita de uma sociedade aberta de intérpretes, um tipo de sociedade em que exista a participação ativa do cidadão no âmbito do processo de tomada de decisão. Uma sociedade informada, que tenha em mente o seu papel perante a Constituição, de modo a efetivá-la, por meio da interpretação aberta e plural, como elemento constitutivo de um processo público. Cuida-se, nesse aspecto, de uma nova releitura da soberania, uma soberania que leve em conta a abertura do Estado Constitucional para o direito internacional.

A soberania está sujeita à evolução e a mudanças, de modo que deve avaliar a sua pretensão de validade e reconhecer seus limites na realidade do mundo atual dos Estados, pois a soberania está ligada sempre à questão da fundamentação da competência e é, em tal medida, uma noção ordenadora que assegura a paz e a liberdade, o que

3 HÄBERLE, Peter. Estado Constitucional Cooperativo. Trad. Marcos Augusto Maliska e Elisete Antoniuk. Rio de Janeiro: Renovar, 2007. p. 18-19.

4 HÄBERLE, Peter. Estado Constitucional Cooperativo. Trad. Marcos Augusto Maliska e Elisete Antoniuk. Rio de Janeiro: Renovar, 2007. p. 19. 
significa, nesse aspecto, a impossibilidade de ser reduzida à "independência" e ao "poder absoluto".5

O livre poder de configuração de um povo ou nação forma parte das peças centrais do pensamento sobre a soberania no Estado Constitucional. Contudo, isso pressupõe um vínculo necessário entre a soberania e um povo mais ou menos homogêneo? No "Estado Constitucional Democrático", somente o "povo"6 pode ser o titular soberano do Estado? Ou as interações supraestatais das mais diversas formas de unificação política limitam a sua "capacidade de decisão"?

A associação entre povo e Estado como ordem concreta que se sustenta na decisão soberana daquele constitui a peça central da legitimação democrática. Nesse aspecto, é de se ressaltar a importância da distinção re-

\footnotetext{
5 KOTZUR, Markus. La soberanía hoy. Palabras clave para un diálogo europeo-latinoamericano sobre un atributo del Estado constitucional moderno. In: HÄBERLE, Peter; KOTZUR, Markus. De la soberanía al derecho constitucional común: palabras clave para un diálogo europeo-latinoamericano. Trad. Héctor Fix-Fierro. México: Universidad Nacional Autónoma de México, Instituto de Investigaciones Jurídicas. 2003, p. 95. (Serie Ensayos Jurídicos, n. 12). Disponível em: <http:// www.bibliojuridica.org/libros/ libro.htm?l=545>. Acesso em: 26 ago. 2007.
}

6 Markus Kotzur questiona que papel desempenha a diversidade pluralista de opiniões, interesses e valores individuais que se escondem por detrás da magnitude abstrata do "povo". Cf. KOTZUR, Markus. La soberanía hoy. Palabras clave para un diálogo europeo-latinoamericano sobre un atributo del Estado constitucional moderno. In: HÄBERLE, Peter; KOTZUR, Markus. De la soberanía al derecho constitucional común: palabras clave para un diálogo europeo-latinoamericano. Trad. Héctor Fix-Fierro. México: Universidad Nacional Autónoma de México, Instituto de Investigaciones Jurídicas. 2003, p. 95. (Serie Ensayos Jurídicos, n. 12). Disponível em: <http:// www.bibliojuridica.org/libros/ libro.htm?l=545>. Acesso em: 26 ago. 2007. José Joaquim Gomes Canotilho considera "povo" (em sentido político) não como sendo apenas aquele definido por uma norma ou os participantes do sufrágio, tão pouco os membros da "maioria" do processo decisório. Para Canotilho, "povo real" é todo aquele que pertence à comunidade aberta de sujeitos constituintes, ou na visão de Peter Häberle, os membros da sociedade aberta de intérpretes da Constituição Cf. CANOTILHO, José Joaquim Gomes. Direito constitucional e teoria da Constituição. 7. ed. Coimbra: Almedina, 2003. p. 76. Nesse sentido, Häberle conceitua povo em um contexto de um catálogo sistemático de intérpretes da esfera pública pluralista Cf. HÄBERLE, Peter. Hermenêutica constitucional. A sociedade aberta de intérpretes da Constituição: contribuição para a interpretação pluralista e "procedimental" da Constituição. Trad. Gilmar Ferreira Mendes. Porto Alegre: S. A. Fabris, 1997. p. 19-28; HÄBERLE, Peter. Pluralismo y constitución: estudios de teoría constitucional de la sociedad abierta. Trad. Emilio Mikunda Franco. Madrid: Tecnos, 2002. p. 94-97. alizada por Sieyès ${ }^{7}$ entre poder constituinte e poder constituído, pois converte o povo em fundamento originário dos atos soberanos constituintes, de natureza supranacional e presumidamente ilimitada, dos quais derivam a legitimidade de todos os atos de autoridade sujeitos à Constituição. ${ }^{8}$

Todavia, a "decisão livre" - sem limites - do povo constitui uma ficção perigosa. E para solucionar tal tensão, a ideia da nação fundada nos direitos humanos pode ser adotada, tendo em vista que a formação de uma unidade política possui numerosos pontos de referência, em que a premissa antropológica da dignidade humana constitui o mais amplo deles. ${ }^{9}$

Com efeito, povo e Estado não são considerados entes idênticos. O Estado é uma concretização do povo e de seu papel no exercício das funções estatais, pois é um modelo de ordem que permite ao povo atuar politicamente. Logo, o conceito jurídico de povo é insatisfatório para qualificar o sujeito ao qual se atribuem as decisões soberanas, pois o que mais legitima a soberania do povo é a autodeterminação do indivíduo, sua capacidade de produzir uma vontade de maneira livre, sem coação, que transforma a soberania popular em soberania cidadã;

\footnotetext{
7 Em especial, ver SIEYĖS, Emmanuel Joseph. A Constituinte Burguesa (Qu'est-ce que le Tiers Etat?). 4. ed. Rio de Janeiro: Lúmen Juris, 2001.

8 KOTZUR, Markus. La soberanía hoy. Palabras clave para un diálogo europeo-latinoamericano sobre un atributo del Estado constitucional moderno. In: HÄBERLE, Peter; KOTZUR, Markus. De la soberanía al derecho constitucional común: palabras clave para un diálogo europeo-latinoamericano. Trad. Héctor Fix-Fierro. México: Universidad Nacional Autónoma de México, Instituto de Investigaciones Jurídicas. 2003, p. 95. (Serie Ensayos Jurídicos, n. 12). Disponível em: <http://www. bibliojuridica.org/libros/ libro.htm?l=545>. Acesso em: 26 ago. 2007.

9 KOTZUR, Markus. La soberanía hoy. Palabras clave para un diálogo europeo-latinoamericano sobre un atributo del Estado constitucional moderno. In: HÄBERLE, Peter; KOTZUR, Markus. De la soberanía al derecho constitucional común: palabras clave para un diálogo europeo-latinoamericano. Trad. Héctor Fix-Fierro. México: Universidad Nacional Autónoma de México, Instituto de Investigaciones Jurídicas. 2003, p. 9899. (Serie Ensayos Jurídicos, n. 12). Disponível em: <http:// www.bibliojuridica.org/libros/ libro.htm?l=545>. Acesso em: 26 ago. 2007.
} 
cuja "coisa pública" adquire materialidade tanto nos Estados nacionais como nos fenômenos supranacionais. ${ }^{10}$

Como exemplo, há de se mencionar a posição do Tribunal Constitucional Federal alemão (Bundesverfassungsgericht) sobre o conceito de soberania. O TCF vincula-o junto ao povo e à nação, em uma metáfora denominada de "comunidade pessoal de destino", em que tanto o povo como a nação, por um lado, são objetos passivos de um destino comum, mas, por outro, constituem sujeitos que configuram ativamente seu destino político. Dessa forma, a ação do Estado Constitucional em termos de garantia da liberdade e promoção da paz é confiada ao povo, o qual se constitui em uma comunidade democrática como unidade de ação institucionalizada, constitucionalizada e aberta aos espaços de responsabilidade supraestatais. ${ }^{11}$

Assim, a soberania está intimamente relacionada com a proteção internacional dos direitos humanos. No mundo globalizado do século XXI, não apenas os Estados, mas os indivíduos e os grupos sociais se encontram inseridos em uma complexa rede de relações multinacionais. Nesse aspecto, há uma relativização da ligação entre os nacionais e o seu respectivo Estado, pois se concebe a soberania como uma criação a partir da Constituição e das redes de ordenamentos constitucionais parciais. É por isso que a comunidade internacional dos Estados possui um fragmento amplo de soberania em matéria de direitos humanos. Além disso, essa comunidade possui um poder

${ }^{10}$ KOTZUR, Markus. La soberanía hoy. Palabras clave para un diálogo europeo-latinoamericano sobre un atributo del Estado constitucional moderno. In: HÄBERLE, Peter; KOTZUR, Markus. De la soberanía al derecho constitucional común: palabras clave para un diálogo europeo-latinoamericano. Trad. Héctor Fix-Fierro. México: Universidad Nacional Autónoma de México, Instituto de Investigaciones Jurídicas. 2003, p. 100101. (Serie Ensayos Jurídicos, n. 12). Disponível em: <http:// www.bibliojuridica.org/libros/ libro.htm?l=545>. Acesso em: 26 ago. 2007.

${ }^{11}$ KOTZUR, Markus. La soberanía hoy. Palabras clave para un diálogo europeo-latinoamericano sobre un atributo del Estado constitucional moderno. In: HÄBERLE, Peter; KOTZUR, Markus. De la soberanía al derecho constitucional común: palabras clave para un diálogo europeo-latinoamericano. Trad. Héctor Fix-Fierro. México: Universidad Nacional Autónoma de México, Instituto de Investigaciones Jurídicas. 2003, p. 101. (Serie Ensayos Jurídicos, n. 12). Disponível em: <http://www. bibliojuridica.org/libros/ libro.htm?l=545>. Acesso em: 26 ago. 2007. de definição e uma competência de atuação originária sobre a "ordem constitucional parcial". ${ }^{12}$

A noção de soberania como "pessoa" estatal já não possui a claridade que tinha no auge da racionalidade ocidental da construção do conceito de Estado. Diversas forças "corrosivas" atuam no âmbito interno e internacional, desde o final do século XX, como (a) o pluralismo político e social interno, que se opõe à ideia de soberania e à sujeição do indivíduo; (b) a formação de centros de poder alternativos e concorrentes com o Estado, que operam no campo político, econômico, cultural e religioso, com frequência e em dimensões totalmente independentes do território estatal; (c) a progressiva institucionalização, promovida, às vezes, pelos próprios Estados, em contextos que integram seus poderes em dimensões supraestatais, subtraindo, assim, a disponibilidade dos Estados nacionais e (d) a atribuição de direitos aos indivíduos,

que podem manejá-los perante jurisdições internacionais em face da atuação do Estado a que pertencem. ${ }^{13}$

Em função da complexidade instalada, o direito público perde a sua posição central de organizador do sistema jurídico, de ponto unificador tomado como axioma, de modo que o seu significado concreto não deriva mais da soberania, mas que deve passar a ser construído. O direito constitucional, logo, deve encontrar uma combinação que não deriva de um centro, e sim de uma política constitucional fundada em diversas combinações. ${ }^{14}$

As sociedades pluralistas atuais, marcadas pela presença da diversidade de grupos sociais com interesses, ideologias e projetos diferentes, encontram-se em uma situação em que um grupo social não tem força su-

${ }^{12}$ KOTZUR, Markus. La soberanía hoy. Palabras clave para un diálogo europeo-latinoamericano sobre un atributo del Estado constitucional moderno. In: HÄBERLE, Peter; KOTZUR, Markus. De la soberanía al derecho constitucional común: palabras clave para un diálogo europeo-latinoamericano. Trad. Héctor Fix-Fierro. México: Universidad Nacional Autónoma de México, Instituto de Investigaciones Jurídicas. 2003, p. 106. (Serie Ensayos Jurídicos, n. 12). Disponível em: <http://www. bibliojuridica.org/libros/ libro.htm?l=545>. Acesso em: 26 ago. 2007.

${ }^{13}$ ZAGREBELSKY, Gustavo. El derecho dúctil. Ley, derechos, justicia. Trad. Marina Gascón. 7. ed. Madrid: Trotta, 2007. p. 11-12.

${ }^{14}$ ZAGREBELSKY, Gustavo. El derecho dúctil. Ley, derechos, justicia. Trad. Marina Gascón. 7. ed. Madrid: Trotta, 2007. p. 12-13. 
ficiente para estabelecer o seu modo de pensar como o valor determinante, como era com a ideia de soberania do Estado. Assim, as sociedades dotadas de relativismo olham a Constituição não como o documento com a tarefa de estabelecer um projeto pré-determinado de vida em comum, mas como o aporte que confere legitimidade a cada um dos grupos sociais e a possibilidade de estabelecer pelo diálogo constitucional a ideologia orientadora do sistema jurídico. ${ }^{15}$

Nesse aspecto, a Constituição deve ser considerada um processo público, que resulta de uma concepção democrática e pluralista, em que vários agentes atuam no desenvolvimento e na construção do texto constitucional. Trata-se, sobretudo, de uma sucessão de interpretações plurais, com a contraposição sociológica (Ferdinand Lassalle) e jurídica (Konrad Hesse), a fim de abarcar o máximo de conceitos para o desenvolvimento (em todos os sentidos) da sociedade. A Constituição deve ser compreendida como a ordem jurídica fundamental do Estado e da sociedade, abarcando tudo aquilo que constitui a sociedade positivamente estabelecida, compreendendo as estruturas básicas de qualquer sociedade pluralista. Desse modo, as relações dos grupos sociais (estabelecidas na base da tolerância pluralista), a eficácia dos direitos fundamentais nas relações entre particulares, as instituições que evitam o abuso do poder (público e privado), a divisão de poderes, a cultura política, a proteção do meio ambiente, a prática parlamentar, os juízos públicos dos políticos e da mídia, as linhas diretivas dos grupos econômicos, tudo isso são fatores que estruturam uma sociedade nos moldes do espírito "aberto" de Karl Popper. ${ }^{16}$

A ascensão do pluralismo em uma Constituição democrática é uma proposta que abrange soluções e compromissos de possibilidades, que não se configura um projeto com um eixo centralizador e hierarquizante, de cima para baixo, mas uma configuração com a coexistência de valores e princípios com a tendência de caminhar para uma política que supere a exclusão e a imposição da lógica "amigo-inimigo" e que passe a buscar uma

${ }^{15}$ ZAGREBELSKY, Gustavo. El derecho dúctil. Ley, derechos, justicia. Trad. Marina Gascón. 7. ed. Madrid: Trotta, 2007. p. 13.

${ }^{16}$ HÄBERLE, Peter. Pluralismo y constitución: estudios de teoría constitucional de la sociedad abierta. Trad. Emilio Mikunda Franco. Madrid: Tecnos, 2002. p. 87-88 integração a partir de um sistema de redes de valores e procedimentos comunicativos, fundada no consenso. ${ }^{17}$

Nesse sentido, apenas uma concepção instrumental da soberania, a serviço do ser humano, pode justificar qualquer forma de exercício de poder, tendo em vista que a soberania se funda na autodeterminação do indivíduo como elemento central de sua dignidade humana e de seu papel como cidadão ativo no Estado Constitucional e na comunidade política que o sustenta. Dessa forma, o Estado também está vinculado às garantias supraestatais dos direitos humanos, contra as quais não pode alegar como escudo a soberania, pois qualquer soberania só tem sentido se provier da soberania do cidadão. ${ }^{18}$

O direito constitucional e o direito internacional ilustram, por meio das múltiplas relações, a realidade do Estado Constitucional aberto e cooperativo, pois o modelo cooperativo conduz às inter-relações cooperativas de soberania. ${ }^{19}$

${ }^{17}$ ZAGREBELSKY, Gustavo. El derecho dúctil. Ley, derechos, justicia. Trad. Marina Gascón. 7. ed. Madrid: Trotta, 2007. p. 14.

${ }^{18}$ KOTZUR, Markus. La soberanía hoy. Palabras clave para un diálogo europeo-latinoamericano sobre un atributo del Estado constitucional moderno. In: HÄBERLE, Peter; KOTZUR, Markus. De la soberanía al derecho constitucional común: palabras clave para un diálogo europeo-latinoamericano. Trad. Héctor Fix-Fierro. México: Universidad Nacional Autónoma de México, Instituto de Investigaciones Jurídicas. 2003, p. 113114. (Serie Ensayos Jurídicos, n. 12). Disponível em: <http:// www.bibliojuridica.org/libros/ libro.htm?l=545>. Acesso em: 26 ago. 2007. De forma combativa, Christine Peter coaduna com esse posicionamento, uma vez que a soberania existe em favor da liberdade, e não pode ser utilizada como escudo contra os valores contidos no bojo das Convenções Internacionais de proteção dos direitos humanos Cf. SILVA, Christine Oliveira Peter da. Tensões entre o direito constitucional e o direito internacional: uma necessária revisitação do conceito de Estado Soberano. In: CONGRESSO BRASILEIRO DE DIREITO INTERNACIONAL, 9., Curitiba. Anais... Curitiba: Juruá, 2011.

${ }^{19}$ KOTZUR, Markus. La soberanía hoy. Palabras clave para un diálogo europeo-latinoamericano sobre un atributo del Estado constitucional moderno. In: HÄBERLE, Peter; KOTZUR, Markus. De la soberanía al derecho constitucional común: palabras clave para un diálogo europeo-latinoamericano. Trad. Héctor Fix-Fierro. México: Universidad Nacional Autónoma de México, Instituto de Investigaciones Jurídicas. 2003, p. 115116. (Serie Ensayos Jurídicos, n. 12). Disponível em: <http:// www.bibliojuridica.org/libros/ libro.htm?l=545>. Acesso em: 26 ago. 2007. Um exemplo emblemático está no plano econômico, com a Organização Mundial do Comércio (OMC), pois as medidas do comércio internacional e da proteção ambiental somente podem ser efetivadas mediante a cooperação entre os Estados. Essas associações nessas matérias não são mais do que um ato de garantia da soberania. 
Por outro lado, em um fenômeno paralelo, se o Estado não se abre à cooperação com a sociedade civil, perde aqui um pedaço de sua "soberania", entendida como "poder soberano de configuração". ${ }^{20}$ Isso porque o conceito material de soberania se apoia a uma dupla premissa. No conceito jurídico-estatal da soberania tem que estar contido o eixo da coordenação e conjugação dos Estados como momento material, de maneira que seus limites estejam definidos pelo valor próprio do ser humano. Dessa forma, o Estado Constitucional se funda na dignidade humana e no valor próprio da pessoa como "premissa antropológica", mas que contém ao mesmo tempo a dimensão da cooperação, já que para o Estado contemporâneo, o que mais vale para a "magnitude da soberania" é a pluralidade de suas vinculações jurídicas e fáticas.

Assim, um conceito de soberania que seja igualmente válido para a doutrina do direito constitucional como para a do direito internacional já deve pressupor tal “elemento cooperativo”. Nesse sentido, o poder público exercido por unidades estatais e supraestatais surgidas do processo de integração - não pode ser explicado mediante as categorias unidimensionais de uma teoria do Estado

${ }^{20}$ KOTZUR, Markus. La soberanía hoy. Palabras clave para un diálogo europeo-latinoamericano sobre un atributo del Estado constitucional moderno. In: HÄBERLE, Peter; KOTZUR, Markus. De la soberanía al derecho constitucional común: palabras clave para un diálogo europeo-latinoamericano. Trad. Héctor Fix-Fierro. México: Universidad Nacional Autónoma de México, Instituto de Investigaciones Jurídicas. 2003, p. 116. (Serie Ensayos Jurídicos, n. 12). Disponível em: <http://www. bibliojuridica.org/libros/ libro.htm?l=545>. Acesso em: 26 ago. 2007. positivista. Deve, pois, ser buscado a partir da realidade do mundo globalizado dos Estados. ${ }^{21}$

Logo, novos intentos terminológicos substituem a "supremacia absoluta" como característica da soberania. A interação de competências relativas, a "soberania compartilhada", o "poder da organização internacional”, ou o "poder da integração supranacional" constituem outras tantas “palavras-chave”. Não há uma "sobreposição” do direito internacional ou do "direito europeu" à soberania, mas, sim, diversos âmbitos de competência e espaços soberanos que se coordenam entre si e se vinculam por meio de um "mecanismo de engrenagem" de um com o outro. $^{22}$

Nesse contexto, o "contrato social" (pertencente aos institutos liberais - contrato, soberania, EstadoNação) está sendo repensado para se adaptar às novas estruturas do século XXI. Não se trata de revogar o contrato social, mas de adaptá-lo ao ideal da fraternidade ${ }^{23}$

${ }^{21}$ KOTZUR, Markus. La soberanía hoy. Palabras clave para un diálogo europeo-latinoamericano sobre un atributo del Estado constitucional moderno. In: HÄBERLE, Peter; KOTZUR, Markus. De la soberanía al derecho constitucional común: palabras clave para un diálogo europeo-latinoamericano. Trad. Héctor Fix-Fierro. México: Universidad Nacional Autónoma de México, Instituto de Investigaciones Jurídicas. 2003, p. 119-120. (Serie Ensayos Jurídicos, n. 12). Disponível em: <http://www.bibliojuridica.org/libros/libro.htm?l=545>. Acesso em: 26 ago. 2007. Sobre esse ponto, Christine Peter faz uma ressalva: "o possível reconhecimento de que o Estado Constitucional contemporâneo não mais é soberano, em face de suas inserções no plano da comunidade mundial, não tem o condão de desnaturar o seu papel nesta comunidade internacional, num exercício de autorreconhecimento contínuo, não mais pela força de seus exércitos, mas pela força de suas pautas culturais influenciadoras das práticas globalizadas." Cf. SILVA, Christine Oliveira Peter da. Tensões entre o direito constitucional e o direito internacional: uma necessária revisitação do conceito de Estado Soberano. In: CONGRESSO BRASILEIRO DE DIREITO INTERNACIONAL, 9., Curitiba. Anais... Curitiba: Juruá, 2011.

${ }^{22}$ KOTZUR, Markus. La soberanía hoy. Palabras clave para un diálogo europeo-latinoamericano sobre un atributo del Estado constitucional moderno. In: HÄBERLE, Peter; KOTZUR, Markus. De la soberanía al derecho constitucional común: palabras clave para un diálogo europeo-latinoamericano. Trad. Héctor Fix-Fierro. México: Universidad Nacional Autónoma de México, Instituto de Investigaciones Jurídicas. 2003, p. 120 121. (Serie Ensayos Jurídicos, n. 12). Disponível em: <http:// www.bibliojuridica.org/libros/ libro.htm?l=545>. Acesso em: 26 ago. 2007.

${ }^{23}$ Cf. HÄBERLE, Peter. Libertad,igualdad, fraternidad: 1789 como historia, actualidad y futuro del Estado Constitucional. Trad. Ignacio Gutiérrez Gutiérrez. Madri: Minima Trotta, 1998. 
da Revolução Francesa. O indivíduo sempre foi o centro da discussão do sistema jurídico, e isso foi revelado pelo desenvolvimento dos valores da liberdade e igualdade. Contudo, o desenvolvimento do sujeito não pode ser egoísta, e a evolução com o aspecto da fraternidade revela o caráter universal da importância do sujeito. ${ }^{24}$

A soberania não pode significar uma blindagem contra as dificuldades que o reconhecimento dos direitos humanos possa induzir nos diversos sistemas constitucionais. Por essa razão, é necessário encontrar novos mecanismos para enfrentar os problemas práticos que a experiência globalizada nos apresenta, e a participação do sujeito como interlocutor qualificado no processo de construção dos direitos humanos é uma delas. ${ }^{25}$

Sendo assim, a escolha do Estado Constitucional pela cooperação internacional, principalmente em matéria de direitos humanos, tem o condão de "estruturar" a soberania, muito mais do que a "desprezar". A relativização da soberania não conduz a "dizer adeus", mas sim em uma releitura como "garantia estrutural". ${ }^{26}$

\section{A construção da racionalidade social na so- berania e o seu efeito nos sistemas regionais de proteção dos direitos humanos}

Discute-se um processo amplo de mudança, o qual desloca as estruturas e processos centrais das atuais sociedades e abala os quadros de referência, responsáveis por conferir aos indivíduos uma ancoragem estável no mundo social. Trata-se de uma "crise de identidade" em que as antigas noções de identidade - que estabilizaram

\footnotetext{
${ }^{24}$ Cf. ROCHA, Maria Elizabeth Guimarães Teixeira. Limitação dos mandatos legislativos: uma nova visão do contrato social. Porto Alegre: S. A. Fabris, 2002.

${ }^{25}$ Cf. SILVA, Christine Oliveira Peter da. Tensões entre o direito constitucional e o direito internacional: uma necessária revisitação do conceito de Estado Soberano. In: CONGRESSO BRASILEIRO DE DIREITO INTERNACIONAL, 9., Curitiba. Anais... Curitiba: Juruá, 2011.

${ }^{26}$ KOTZUR, Markus. La soberanía hoy. Palabras clave para un diálogo europeo-latinoamericano sobre un atributo del Estado constitucional moderno. In: HÄBERLE, Peter; KOTZUR, Markus. De la soberanía al derecho constitucional común: palabras clave para un diálogo europeo-latinoamericano. Trad. Héctor Fix-Fierro. México: Universidad Nacional Autónoma de México, Instituto de Investigaciones. Jurídicas. 2003, p. 95. (Serie Ensayos Jurídicos, n. 12). Disponível em: <http://www. bibliojuridica.org/libros/ libro.htm?l=545>. Acesso em: 26 ago. 2007.
}

o mundo social - estão em declínio, em virtude da assunção de novas identidades, fragmentadoras do sujeito moderno, considerado unificado. ${ }^{27}$

A crise de identidade surge a partir do processo de deslocamento ou "descentração" do sujeito, que consiste no deslocamento dos indivíduos tanto de seu lugar no mundo social e cultural quanto dele próprio. Trata-se de uma mudança estrutural que está transformando as sociedades no final do século XX e início do século XXI, com a fragmentação das paisagens culturais - de classe, gênero, sexualidade, etnia, raça e nacionalidade - que mantinha sólidas as localizações do indivíduo no plano da identidade social e no plano da identidade pessoal, como sujeito integrado. ${ }^{28}$

O sistema jurídico como um todo convive com pelo menos três concepções diferentes de identidade no seu cotidiano: (a) a identidade do sujeito do Iluminismo; (b) a identidade do sujeito sociológico e (c) a identidade do sujeito pós-moderno.

O sujeito do Iluminismo centra-se na perspectiva individualista do eu, na identidade de uma pessoa, de um indivíduo totalmente centrado e unificado, dotado das capacidades de razão, de consciência e de ação. ${ }^{29}$

Por outro lado, a noção de sujeito sociológico reflete a complexidade na qual o mundo moderno a reflete e a consciência de que o centro não é apenas a autoconsciência do sujeito, mas sim a relação com outras pessoas, em que se verifica a troca de experiência e valores, sentidos e símbolos - em resumo, a formação da cultura. ${ }^{30}$

A partir dessa concepção, a identidade é formada pela interação do eu com a sociedade. Constitui o núcleo essencial do sujeito, o "eu real", mas ele dialoga continuamente com as esferas culturais "exteriores" e as outras identidades por elas oferecidas. Desse modo, há o

${ }^{27}$ HALL, Stuart. A identidade cultural na pós-modernidade. 11. ed. Trad. Tomaz Tadeu da Silva e Guacira Lopes Louro. Rio de Janeiro: DP\&A, 2006. p. 7.

${ }^{28}$ HALL, Stuart. A identidade cultural na pós-modernidade. 11. ed. Trad. Tomaz Tadeu da Silva e Guacira Lopes Louro. Rio de Janeiro: DP\&A, 2006. p. 9.

${ }^{29}$ HALL, Stuart. A identidade cultural na pós-modernidade. 11. ed. Trad. Tomaz Tadeu da Silva e Guacira Lopes Louro. Rio de Janeiro: DP\&A, 2006. p. 10-11.

${ }^{30}$ HALL, Stuart. A identidade cultural na pós-modernidade. 11. ed. Trad. Tomaz Tadeu da Silva e Guacira Lopes Louro. Rio de Janeiro: DP\&A, 2006. p. 11. 
preenchimento do espaço pessoal com a esfera pública, com o alinhamento dos sentimentos subjetivos com os lugares objetivos, a partir da projeção dos valores individuais nessas identidades culturais e, simultaneamente, a internalização dos significados e valores do mundo externo. Assim, o sujeito é "costurado" à estrutura a partir da identidade. ${ }^{31}$

Anteriormente, com uma identidade unificada e estável, o sujeito passa por grandes transformações: passa agora a ser considerado um sujeito fragmentado, composto de várias identidades; e em função das mudanças estruturais e institucionais, as identidades estão entrando em colapso, sendo que o próprio processo de identificação do sujeito constitutivo tornou-se mais provisório, variável e problemático. ${ }^{32}$

Passa-se a ter um reconhecimento de uma identidade do sujeito no âmbito dos sistemas regionais de proteção dos direitos humanos. Em função da fragmentação, além do papel de vítima, o sujeito passa a ter o papel de fomentador do sistema, com o acesso universal, contribuindo para o processo de tomada de decisão em matéria da luta contra a violação dos direitos humanos.

Isso porque, sob certas circunstâncias, seus diferentes elementos e identidades podem ser conjuntamente articulados, no entanto, sua estrutura da identidade sempre permanece aberta. Embora seja uma articulação parcial, cuida-se de uma "recomposição da estrutura em torno de pontos nodais particulares de articulação" ${ }^{\prime 3}$ que, na verdade, constitui a formulação de um sujeito adaptado à realidade dos sistemas de proteção dos direitos humanos.

Todavia, cada sistema regional parte de pelo menos um ponto comum, a proteção de direitos humanos, mas desenvolve identidades culturais diversificadas, a partir da relação de pertencimento às culturas étnicas, raciais, linguísticas, religiosas e de cada Estado-Parte. ${ }^{34}$ Desse modo, essa

${ }^{31}$ HALL, Stuart. A identidade cultural na pós-modernidade. 11. ed. Trad. Tomaz Tadeu da Silva e Guacira Lopes Louro. Rio de Janeiro: DP\&A, 2006. p. 11-12.

${ }^{32}$ HALL, Stuart. A identidade cultural na pós-modernidade. 11. ed. Trad. Tomaz Tadeu da Silva e Guacira Lopes Louro. Rio de Janeiro: DP\&A, 2006. p. 12.

${ }^{33}$ HALL, Stuart. A identidade cultural na pós-modernidade. 11. ed. Trad. Tomaz Tadeu da Silva e Guacira Lopes Louro. Rio de Janeiro: DP\&A, 2006. p. 18-19.

${ }^{34}$ HALL, Stuart. A identidade cultural na pós-modernidade. 11. ed. Trad. Tomaz Tadeu da Silva e Guacira Lopes Louro. Rio de Janeiro: DP\&A, 2006. p. 8. noção de multiculturalismo também se apresenta como elemento metodológico do processo de tomada de decisão das cortes regionais de proteção dos direitos humanos.

No âmbito europeu, há uma prevalência de precedentes, decorrentes do peticionamento dos indivíduos, que envolvam casos relacionados a torturas de determinados grupos ou etnias, como os ciganos, seja no âmbito de prisões, ou seja por autoridades públicas que atuam fora do cárcere.

No caso Moldovan e outros vs. Romênia, um grupo de origem cigana levou o caso até a E.C.H.R. em virtude de uma série de atos perpetrados com a força estatal contra o grupo, cujo intuito era o de expulsá-los da cidade. As pessoas do grupo foram perseguidas, tiveram suas casas destruídas e viveram em condições desumanas por mais de 10 anos. Conforme apreciou a E.C.H.R., as instâncias judiciais não cumpriram seu papel de investigação e indenização das vítimas, razão pela qual a E.C.H.R. condenou o Estado da România na violação de diversos artigos da Convenção Europeia, por terem atuado de maneira discriminatória e negado ao grupo étnico o pleno acesso à justiça. ${ }^{35}$

De acordo com as circunstâncias especiais do caso, a E.C.H.R. reconheceu o desrespeito à dignidade da pessoa humana, bem como alargou a amplitude da proteção prevista no artigo $3^{\circ}$ da Convenção, na medida em que impôs a possibilidade de existência de tratamento desumano ou degradante, ainda que uma pessoa não esteja sob a custódia estatal; isto é, não se cuida de qualquer situação degradante ou desumana, mas sim de hipótese em que as forças do Estado atuam, embora de maneira contrária ao sistema jurídico.

Portanto, verifica-se que o sistema europeu possui uma atenção a seus julgados acerca de violação de grupos e minorias, principalmente aqueles discriminados com ação desumana ou degradante do Estado. A Convenção

\footnotetext{
${ }^{35}$ EUROPEAN COURT OF HUMAN RIGHTS. Second Section. Moldovan and others vs. Romania (Applications $n^{\circ}(s)$ 41138/98 and 64320/01), j. 12.7.2005. Disponível em: <http:// www.echr.coe.int/>. Acesso em: 25 set. 2008. Ver, em especial, o $\$ 113$ : "In the light of the above, the Court finds that the applicants' living conditions and the racial discrimination to which they have been publicly subjected by the way in which their grievances were dealt with by the various authorities, constitute an interference with their human dignity which, in the special circumstances of this case, amounted to "degrading treatment" within the meaning of Article 3 of the Convention."
} 
Europeia institucionalizou essa preocupação no seu artigo 14 , ao discorrer sobre a proteção das minorias:

O gozo dos direitos e liberdades enunciados na presente Convenção deve ser garantido sem discriminação por qualquer motivo, como sexo, raça, cor, língua, religião, opinião política ou outra, origem nacional ou social, de associação, com uma minoria nacional, propriedade, nascimento ou qualquer outra situação. ${ }^{36}$

A Corte veda toda a discriminação que não tenha uma justificativa objetiva e razoável realizada entre indivíduos em situações análogas. ${ }^{37}$ A princípio, o direito de não discriminação se vincularia a outro direito protegido pela Convenção, não possuindo uma "existência independente". No entanto, a E.C.H.R. equiparou o conteúdo desse direito aos demais, concedendo-lhe autonomia no âmbito da Convenção, pois o artigo 14 "faz parte integrante de cada uma das disposições, garantido os direitos e liberdades". 38

O Protocolo no 12 ultrapassa os limites do artigo 14 da Convenção Europeia e confere eficácia irradiante ao direito à não discriminação, estendendo-a para o gozo de todo o direito garantido ao indivíduo pelo ordenamento jurídico nacional, proibindo toda e qualquer discriminação por parte de qualquer autoridade pública. ${ }^{39}$

Por outro lado, o sistema interamericano possui uma abordagem diversa quanto ao tema multiculturalismo. Institucionalmente, depreende-se do texto da Convenção Americana, a partir da interpretação sistêmica do artigo $1^{\circ}$ com o artigo 24 , a proteção das minorias contra a discriminação.

${ }^{36}$ Previsão no original, a fim de acompanhar a tradução: “The enjoyment of the rights and freedoms set forth in this Convention shall be secured without discrimination on any ground such as sex, race, colour, language, religion, political or other opinion, national or social origin, association, with a national minority, property, birth or other status."

${ }^{37}$ EUROPEAN COURT OF HUMAN RIGHTS. Fourth Section. Salgueiro da Silva Mouta vs. Portugal (Application $n^{\circ}$ 33290/96), j. 21.12.1999. Disponível em: <http://www.echr. coe.int $>$. Acesso em: 27 jun. 2008. Ver, em especial, trecho do $₫ 26$ : “The Court reiterates that in the enjoyment of the rights and freedoms guaranteed by the Convention, Article 14 affords protection against different treatment, without an objective and reasonable justification, of persons in similar situations (see the Hoffmann judgment cited above, p. $58, \S 31)$."

${ }^{38}$ LIMA, José Antonio Farah Lopes de. Convenção europeia de direitos humanos. São Paulo: J. H. Mizuno, 2007. p. 43.

${ }^{39}$ LIMA, José Antonio Farah Lopes de. Convenção europeia de direitos humanos. São Paulo: J. H. Mizuno, 2007. p. 43.
Além disso, verifica-se pela evolução do sistema a existência de protocolos adicionais à Convenção Americana que cuidam dessa espécie de abordagem de temas: Protocolo Adicional à Convenção sobre Direitos Humanos em Matéria de Direitos Econômicos, Sociais e Culturais; no Protocolo à Convenção Americana sobre Direitos Humanos Referente à Abolição da Pena de Morte; na Convenção Interamericana para Prevenir e Punir a Tortura; na Conferência Interamericana sobre a Eliminação de Todas as Formas de Discriminação Contra Pessoas com Deficiência e na Convenção Interamericana para Prevenir, Punir e Erradicar a Violência contra a Mulher.

Acerca da atuação da CORTE I.D.H. nesse tema, destaca-se na sua competência consultiva a OC-11/90, ao tratar da possibilidade de esgotamento dos recursos internos dos indigentes, e a OC-17/2002, sobre a condição jurídica e os direitos humanos das crianças.

Quanto ao exercício da competência judicial, destaca-se o caso da Comunidade Indígena Yakye Axa vs. Paraguai, o qual debate a questão do direito à identidade cultural. Em resumo, a CORTE I.D.H. adota nesse caso uma interpretação evolutiva e dinâmica, semelhante à jurisprudência da E.C.H.R., para reconhecer a Convenção Americana como um instrumento vivo, capaz de acompanhar as evoluções temporais e as condições de vida atuais. Nesse aspecto, a CORTE I.D.H. considerou a identidade cultural como um componente agregado ao próprio direito à vida "lato sensu". 40 Assim, se violada a identidade cultural, a própria vida será inevitavelmente violada. ${ }^{41}$

Com efeito, a CORTE I.D.H. volta-se para a questão do direito à verdade - como aspecto institucional. ${ }^{42}$ O sistema interamericano esboça um posicionamento de ser contra as leis de anistia, em face do confronto com os valores fundamentais reconhecidos pelos direitos internacionais dos direitos humanos. $\mathrm{O}$ direito à verdade, nessa perspectiva, combate a tortura, as execuções sumárias - extrajudiciais ou arbitrárias - e o desaparecimento

${ }^{40}$ CORTE INTERAMERICANA DE DERECHOS HUMANOS. Caso comunidad indígena Yakye Axa vs. Paraguay. Sentencia de 17.6.2005 (Fondo, Reparacíones y Costas). Disponível em: $<$ http://www.corteidh.or.cr/>. Acesso em: 22 out. 2008.

${ }^{41}$ PIOVESAN, Flávia. Direitos humanos e o direito constitucional internacional. 9. ed. rev. ampl. e atual. São Paulo: Saraiva, 2008. p. 269.

${ }^{42}$ PIOVESAN, Flávia. Direitos humanos e o direito constitucional internacional. 9. ed. rev. ampl. e atual. São Paulo: Saraiva, 2008. p. 266-267. 
forçado de pessoas. Trata-se, nesse contexto, de uma adequação com a realidade latino-americana.

Logo, o processo de reconhecimento dos direitos da pessoa humana não tende à difusão de um modelo único, a partir de um ponto único. Concentra-se, sobretudo, na emergência de diversos pontos (ou regiões) do mundo, nascendo de uma vontade compartilhada de reconhecer direitos comuns a todos os seres humanos. Nesse aspecto, a universalidade dos direitos fundamentais à pessoa humana implica troca de culturas e valores e não desejo de se construir um sentido único e universal. Logo, cada sociedade experiencia, de algum modo, os aspectos dos direitos humanos à sua maneira. Deve-se, por outro lado, aproximar as "diferentes culturas" a fim de que elas se enriqueçam com a troca mútua de experiências e procedimentos. ${ }^{43}$

\section{A premissa dos valores constitucionais na atuação do sujeito soberano perante os sis- temas regionais de proteção dos direitos hu- manos: o racionalismo crítico como guia para o pensamento a partir da lógica dos direitos fundamentais}

O racionalismo crítico de Popper é o marco filosófico mais adequado para o desenvolvimento da sociedade aberta, pois o conteúdo material dos valores constitucionais (e seus elementos estruturais), espalhados pelos documentos oficiais em matéria de direitos humanos, mostra-se congruente com os elementos de tal teoria crítica. $^{44}$

A teoria constitucional de cunho pluralista - situada entre o conservadorismo e a inovação - busca sempre seu próprio caminho. As teorias científico-sociais sempre - em último extremo e de maneira mais ou menos direta - estão surgindo oriundas de uma prática constitucional plural na liberdade. Tal modelo exige unir teorias epistemológicas com outras puramente científicas, próprias do racionalismo crítico, ${ }^{45}$ para efetuar a resposta da raciona-

${ }^{43}$ LIMA, José Antonio Farah Lopes de. Convenção europeia de direitos humanos. São Paulo: J. H. Mizuno, 2007. p. 19.

${ }^{44}$ HÄBERLE, Peter. Pluralismo y constitución: estudios de teoría constitucional de la sociedad abierta. Trad. Emilio Mikunda Franco. Madrid: Tecnos, 2002. p. 111.

${ }^{45}$ HÄBERLE, Peter. Pluralismo y constitución: estudios de teoría constitucional de la sociedad abierta. Trad. Emilio Mikunda Franco. Madrid: Tecnos, 2002. p. 105. lidade social: a leitura da realidade a partir dos valores contidos nos direitos fundamentais.

Os direitos fundamentais são concebidos segundo uma estrutura dual: junto a sua concepção tradicional de direitos subjetivos frente ao poder público, aparecem como normas objetivas que expressam conteúdo axiológico de validade universal e que, tomadas em conjunto, dão origem a um sistema de valores que afeta não apenas o ordenamento constitucional, mas o sistema jurídico em seu conjunto. ${ }^{46}$

Desse caráter objetivo valorativo dos direitos fundamentais, o Bundesverfassungsgericht deduz a eficácia (ou efeito) irradiante dos direitos fundamentais (Ausstrahlungswirkung) sobre todo o sistema jurídico. ${ }^{47} \mathrm{Em}$ função desse efeito, as relações do direito constitucional com outros ramos do Direito devem ser revistas, pois os direitos fundamentais atuam como um princípio de interpretação de todos os preceitos jurídicos. ${ }^{48}$ Como assinala Konrad Hesse, os direitos fundamentais:

[...] [i]nfluem em todo o Direito - incluído o direito administrativo e o direito processual - não só quando tem por objeto as relações jurídicas dos cidadãos com os poderes públicos, senão também quando regula as relações jurídicas entre particulares. Em tal medida servem de pauta tanto para o legislador como para as demais instâncias que aplicam o Direito, todas as quais ao estabelecer, interpretar e por em prática normas jurídicas haverão de ter em conta o efeito dos direitos fundamentais. ${ }^{49}$

Nesse aspecto, os direitos fundamentais ganham a cada dia a função "pluridimensional", ${ }^{50}$ na medida em que se manifesta no âmbito dos processos de crescimento

${ }^{46}$ CRUZ, Luis M. La Constitución como orden de valores. Problemas jurídicos y políticos. Un estudio sobre los orígenes del neoconstitucionalismo. Colección filosofía, derecho y sociedad. Granada: Comares, 2005. p. 15.

47 ALEMANHA. Bundesverfassungsgericht. BVerfGE 7, 198 (207). Disponível em: <http://www.bverfg.de>. Acesso em: 26 jul. 2008.

${ }^{48}$ CRUZ, Luis M. La Constitución como orden de valores. Problemas jurídicos y políticos. Un estudio sobre los orígenes del neoconstitucionalismo. Colección filosofía, derecho y sociedad. Granada: Comares, 2005. p. 16.

${ }^{49}$ HESSE, 1996. p. 93 apud CRUZ, Luis M. La Constitución como orden de valores. Problemas jurídicos y políticos. Un estudio sobre los orígenes del neoconstitucionalismo. Colección filosofía, derecho y sociedad. Granada: Comares, 2005. p. 16.

${ }^{50}$ HÄBERLE, Peter. La garantía del contenido esencial de los derechos fundamentales. Trad. Joaquín Brage Camazano. Madrid: Dykinson, 2003. Estudio preliminar de Francisco Fernández Segado, p. LIV. 
e etapa evolutiva um refinamento dos meios e das possibilidades do texto por meio da interpretação constitucional. ${ }^{51}$ Assim, os direitos fundamentais apresentam-se em três dimensões protetoras: (a) direito fundamental clássico, mais conhecida como perspectiva subjetiva; (b) garantia institucional, que se vislumbra na perspectiva objetiva e (c) norma fundamental valorativa, dimensão que adquire importância nos dias atuais, tendo em vista a dinâmica que se impõe na expressão de valores
${ }^{51} \mathrm{O}$ conceito de interpretação constitucional deve ser compreendido como o mais amplo possível, uma vez que abarca o sentido estrito não só dos processos jurídicos correntes, isto é, dos ventilados no âmbito dos tribunais, mas também os que os cidadãos se façam presentes de forma ativa e passiva, especialmente enquanto aos atos da comunidade política, já que todos os processos relativizam os valores constitucionais (no sentido anglo-saxão do termo "constitutional law in public action") Cf. HÄBERLE, Peter. Pluralismo y constitución: estudios de teoría constitucional de la sociedad abierta. Trad. Emilio Mikunda Franco. Madrid: Tecnos, 2002. p. 88. constitucionais para o âmbito internacional e entre os contextos dos Estados Constitucionais. ${ }^{5253}$

${ }^{52}$ HÄBERLE, Peter. El Estado Constitucional. México: Instituto de Investigações Jurídicas, UNAM, 2003. Disponível em: $<$ http://www.bibliojuridica.org/libros/libro.htm?l=14>. Acesso em: 26 jan. 2008. p. 108-109.

${ }^{53}$ A primeira manifestação com essa pluridimensionalidade ocorreu no julgamento (BVerfGE 6, 55, em 17.1.1957) sobre a proteção do casamento e da família contra a "divisão tributária" (Steuersplitting) do imposto de renda pelo Tribunal Constitucional Federal alemão (TCF). O Bundesverfassungsgericht verificou a incompatibilidade do $\$ 26$ da Lei do Imposto de Renda (Einkommensteuergesetz - EstG) de 1951 com o artigo $6^{\circ}$, item I, da Lei Fundamental de Bonn (Grundgesetz - GG), o qual prevê que "o casamento e a família encontram-se sob proteção especial da ordem estatal”. O $\$ 26$ EstG 1951 foi objeto de controle concreto proposto pelo Tribunal Financeiro de Munique, uma vez que esse dispositivo afastou-se do princípio da individualização tributária ao considerar, como base de cálculo para a aferição do imposto de renda devido, a simples soma das rendas dos cônjuges. Como o imposto de renda tem uma alíquota progressiva, o cálculo conjunto representava uma desvantagem em face da tributação de solteiros. O Tribunal apresentante considera que a Lei Fundamental estabelece a "divisão tributária" (Steuersplitting), razão pela qual submeteu o caso ao TCF. O Bundesverfassungsgericht considerou que o artigo $6^{\circ}$ I GG é um direito constitucional concretamente vinculante para o legislador, uma vez que se proíbe de onerar o casamento e a família por meio de intervenções perturbadoras oriundas da ordem estatal. No caso, o comprometimento do status quo dos cônjuges por meio da declaração conjunta do imposto de renda fere o princípio constitucional da tributação pessoal (individual), em prejuízo daqueles que vivem no estado civil de casado, representando, portanto, uma intervenção perturbadora. Na fundamentação do caso, asseverou o TCF que o artigo $6^{\circ}$ I GG não é apenas um "direito fundamental clássico" para a proteção da esfera privada específica do casamento e da família, assim como também não é somente uma garantia institucional (das instituições sociais "casamento" e "família", isto é, de sua estrutura essencial, de sua eficácia na realidade jurídica, representada pelo núcleo normativo do direito de família e matrimonial); ela representa também uma norma-princípio, ou seja, uma decisão valorativa vinculante para toda a área do direito privado e público que se ocupe do casamento e da família. Assim, o artigo $6^{\circ}$ I GG é uma norma-princípio que encerra uma decisão axiológica, pois coloca o casamento e a família como célula embrionária de qualquer comunidade, cujo significado não pode ser comparado a nenhum outro vínculo humano sob proteção especial da ordem estatal. Logo, como juízo de valor vinculante para todo o âmbito do direito privado e público que se ocupe do casamento e da família, o artigo $6^{\circ}$ I GG cumpre outras funções, de modo que, para o Bundesverfassungsgericht, é escopo de a jurisprudência constitucional perscrutar as diferentes funções de uma norma constitucional, principalmente de um direito fundamental, a fim de se dar preferência à interpretação que desenvolva melhor a eficácia jurídica da norma em debate. Cf. MARTINS, Leonardo (Org.). Cinquenta anos de jurisprudência do Tribunal Constitucional Federal Alemão. Coletânea original: Jürgen Schwabe. Montevideo; Uruguay: Konrad-Adenauer-Stiftung, 2005. p. 501-505. 
Por essa razão, o desenvolvimento do constitucionalismo a partir de $1945,{ }^{54}$ após a Segunda Guerra Mundial, buscou colocar a Constituição como uma ordem de valores, a qual, a partir da premissa antropológica cultural da dignidade humana, ${ }^{55}$ passaria a irradiar o seu conteúdo normativo por todo o ordenamento jurídico. A dignidade humana, predominante nas constituições da sociedade ocidental, torna-se um valor ético fundamental, uma garantia de validade universal que afeta todo o sistema jurídico em seu conjunto. Ela não pode ser considerada um direito fundamental de caráter subjetivo, mas uma norma jurídica de cunho objetivo, sem qualquer limitação, em que se determina uma base para todo o sistema de valores, que serve como critério interpretativo de todos os direitos fundamentais. ${ }^{56}$

A fórmula da dignidade da pessoa humana se mostra como um meio para a introdução da ideologia no direito constitucional. ${ }^{57}$ Com efeito, a abertura às ideologias fez com que o seu agrupamento nas Constituições criasse uma ideologia constitucional na qual realizasse a passagem do Estado de Direito ao Estado Constitucional. Assim, verifica-se uma mudança na concepção de se ler o sistema jurídico: ${ }^{58}$ a lei, dantes principal fundamento do Estado de Direito, agora passa a estar subordinada à Constituição, a qual reorienta o ordenamento a partir de um sistema de valores, transformando a supremacia da lei em supremacia da Constituição, cuja profunda mudança afeta necessariamente o conceito de Direito. ${ }^{59}$

${ }^{54}$ ZAGREBELSKY, Gustavo. El derecho dúctil. Ley, derechos, justicia. Trad. Marina Gascón. 7. ed. Madrid: Trotta, 2007. p. 9-40.

${ }^{55}$ HÄBERLE, Peter. Estado Constitucional Cooperativo. Trad. Marcos Augusto Maliska e Elisete Antoniuk. Rio de Janeiro: Renovar, 2007. p. 19.

${ }^{56}$ CRUZ, Luis M. La Constitución como orden de valores. Problemas jurídicos y políticos. Un estudio sobre los orígenes del neoconstitucionalismo. Colección filosofía, derecho y sociedad. Granada: Comares, 2005. p. 19-24.

${ }^{57}$ CRUZ, Luis M. La Constitución como orden de valores. Problemas jurídicos y políticos. Un estudio sobre los orígenes del neoconstitucionalismo. Colección filosofía, derecho y sociedad. Granada: Comares, 2005. p. 58.

${ }^{58}$ Cf. SILVA, Christine Oliveira Peter da. Como se lê a Constituição: abordagem metodológica da interpretação constitucional. Direito Público, Porto Alegre, v. 1, n. 6, p. 136-152, trimestral, 2004.

${ }^{59}$ ZAGREBELSKY, Gustavo. El derecho dúctil. Ley, derechos, justicia. Trad. Marina Gascón. 7. ed. Madrid: Trotta, 2007. p. 34.
As reflexões sobre a formulação da dignidade humana e seu papel no sistema jurídico ${ }^{60}$ conduzem o sujeito ao centro do sistema jurídico, com ênfase no conceito de autodeterminação do indivíduo, em matéria de direitos fundamentais.

A compreensão dessa nova formulação do papel do sujeito e sua autodeterminação quanto aos direitos fundamentais pode ser compreendida com o estudo da ideia de status activus processualis.

No aspecto dos direitos fundamentais, Peter Häberle propõe uma nova leitura dos quatro status da teoria de Jellinek, ${ }^{61}$ em especial dos status activus e positivus, a fim de apresentar uma visão participativa dos direitos fundamentais a teor de estes propiciarem uma participação nos diferentes processos de tomada de decisão. Em sintonia com essa nova visão, Häberle crê no surgimento de um novo status - denominado de status activus processualis. Trata-se de um termo em que se deve compreender todo o tipo de procedimento em matéria de direitos fundamentais no qual se transmuda a "reserva de lei" para a "reserva de procedimento", a fim de permitir a participação do indivíduo na multiplicidade de relações jurídicas envolvendo a tomada de decisão. ${ }^{62}$

Logo, em sua aproximação com a realidade, os direitos fundamentais ganham certa "margem de elasticidade" na medida em que seu caráter normativo é trocado pelo instrumental; isto é, cuida-se da procedimentalização dos direitos fundamentais, em função de se obter

${ }^{60}$ Reflexões estas conduzidas e compartilhadas no âmbito do Núcleo de Estudos Constitucionais - NEC, cuja liderança ativa e efetiva se faz na pessoa da professora Christine Oliveira Peter da Silva.

${ }^{61}$ Dentre os quatro status assinalados por Jellinek - activus, negativus, positivus e passivus -, para o teórico o mais importante era o negativo, referente à abstenção do Estado na atuação livre do indivíduo. Na proposta de Häberle, ele passa a ser o último Cf. HÄBERLE, Peter. Pluralismo y constitución: estudios de teoría constitucional de la sociedad abierta. Trad. Emilio Mikunda Franco. Madrid: Tecnos, 2002. p. 193, em especial nota de rodapé no 48). Sobre o desenvolvimento teórico dos quatro status de direitos fundamentais, por todos ver CANOTILHO, José Joaquim Gomes. Direito constitucional e teoria da Constituição. 7. ed. Coimbra: Almedina, 2003.

${ }^{62} \mathrm{HÄBERLE}$, Peter. La garantía del contenido esencial de los derechos fundamentales. Trad. Joaquín Brage Camazano. Madrid: Dykinson, 2003. Estudio preliminar de Francisco Fernández Segado, p. LIV-LV; ver também HÄBERLE, Peter. Pluralismo y constitución: estudios de teoría constitucional de la sociedad abierta. Trad. Emilio Mikunda Franco. Madrid: Tecnos, 2002. p. 193-195. 
uma maior capacidade de adaptação em situações de permanente mudança. ${ }^{63}$

A ideia procedimental constitui um meio de funcionalidade e de ponderação para a concretização dos direitos fundamentais. A atuação pelo status activus processualis no procedimento contribui para a formação do núcleo essencial dos direitos fundamentais. Logo, resulta evidente quanto decisivos são os procedimentos respectivos da base real sobre a qual se assentam os próprios direitos fundamentais, pois a força disciplinar notória do procedimento em si se tornará a racionalidade adotada pelo indivíduo no âmbito social. ${ }^{64}$

Atualmente, se os direitos fundamentais são tidos como instrumento emancipatório de uma "globalização alternativa da cidadania", ${ }^{65}$ e se o que está hoje em causa é a criação de novos espaços políticos, a ampliação do espaço público, a criação de novas identidades e de novos sujeitos coletivos, capazes de aprofundar os direitos humanos no próprio processo de luta pela democracia, então os tribunais adquirem uma importância cada vez maior na proteção dos indivíduos face à pulverização dos centros de tomada de decisão. ${ }^{66}$

Nesse contexto, a interpretação e aplicação dos direitos humanos pelas cortes dos sistemas regionais de proteção são necessariamente influenciadas pela evolução da sociedade. ${ }^{67} \mathrm{E}$ essa evolução está presente na fórmula da dignidade da pessoa humana, a qual permite, a

${ }^{63}$ HÄBERLE, Peter. Pluralismo y constitución: estudios de teoría constitucional de la sociedad abierta. Trad. Emilio Mikunda Franco. Madrid: Tecnos, 2002. p. 165.

${ }^{64}$ HÄBERLE, Peter. La garantía del contenido esencial de los derechos fundamentales. Trad. Joaquín Brage Camazano. Madrid: Dykinson, 2003. Estudio preliminar de Francisco Fernández Segado, p. LIV-LV; ver também HÄBERLE, Peter. Pluralismo y constitución: estudios de teoría constitucional de la sociedad abierta. Trad. Emilio Mikunda Franco. Madrid: Tecnos, 2002. p. 198-199, 216 e 224.

${ }^{65}$ Como ensina Boaventura de Sousa Santos: "Os direitos humanos só poderão desenvolver seu potencial emancipatório se se libertarem do seu falso universalismo e se tornarem verdadeiramente multiculturais." Cf. SANTOS, Boaventura de Sousa. Por uma concepção multicultural de direitos humanos. DHnet: Direitos humanos na internet, multiculturalismo e direitos humanos. Disponível em: <http://www.dhnet.org. br/cultura/multiculturalismo/>. Acesso em: 5 out. 2008.

${ }^{66}$ SOUSA, João Ramos de. Apresentação: ainda há juízes em Estrasburgo. Sub Judice: Justiça e sociedade. Direitos humanos no Tribunal Europeu, Lisboa, n. 28, p. 8, abr./set. 2004.

${ }^{67}$ BARRETO, Irineu Cabral. A Convenção europeia dos direitos do homem anotada. 3. ed. Coimbra: Coimbra Editora, 2005. p. 33. partir da autodeterminação do indivíduo em matéria de direitos fundamentais, aproximar direitos humanos e direitos fundamentais, em função do valor contido no núcleo essencial de cada um desses instrumentos.

Os valores fundamentais contidos no conteúdo do núcleo essencial dos direitos humanos possuem um ideal comum de atingir todos os cidadãos de todas as partes do globo, a fim de alcançar uma consciência jurídica comum. Nessa assertiva, tais valores fundamentais possuem duas perspectivas: (1) a sua universalidade permite a qualquer pessoa invocá-los contra qualquer Estado ou particular e invocar para si as condições humanas inerentes, independentemente do local e da situação concreta posta; e (2) o respeito dos princípios e regras relativos aos direitos fundamentais da pessoa humana passou a constituir uma obrigação de todos perante todos (entes estatais, atores civis e econômicos). ${ }^{68}$

Com efeito, estão sendo produzidas mudanças nos pontos de referência dos direitos fundamentais, em cuja base os valores fundamentais estão sendo estruturados. É quando se vê a necessidade de reestruturar todos eles, no sentido de uma dogmática destinada a fazê-los efetivos em conjunto, dentro do âmbito social do interesse público. ${ }^{69}$

A dogmática de cunho aberto ostenta as mudanças e as transformações que os direitos fundamentais se referem, pois, em função da dinâmica dos atores, tal dogmática deverá refinar suas sistematizações, figuras e instrumentos, mantendo-os flexíveis e, sobretudo, deve evitar conclusões precipitadas, já que se cuida de elaborar uma sensibilização em matéria de direitos fundamentais frente à própria realidade social. ${ }^{70}$

Posta a serviço de garantias e avais de racionalidade dos direitos fundamentais, a dogmática aberta deve desenvolver-se no âmbito da ciência jurídica. Ao extirpar definitivamente certos dogmas, poderá concretizar efetivamente os direitos fundamentais, abrindo-se a uma nova compreensão constitucional. Por outro lado, a dogmática

${ }^{68}$ BARRETO, Irineu Cabral. A Convenção europeia dos direitos do homem anotada. 3. ed. Coimbra: Coimbra Editora, 2005. p. 22.

${ }^{69}$ HÄBERLE, Peter. Pluralismo y constitución: estudios de teoría constitucional de la sociedad abierta. Trad. Emilio Mikunda Franco. Madrid: Tecnos, 2002. p. 184.

${ }^{70}$ HÄBERLE, Peter. Pluralismo y constitución: estudios de teoría constitucional de la sociedad abierta. Trad. Emilio Mikunda Franco. Madrid: Tecnos. p. 185-186. 
dos direitos fundamentais possui sua própria interpretação e categorias axiológicas de natureza múltipla, as quais oferecem referências orientadoras à racionalidade. Desse modo, a racionalidade existente nos direitos fundamentais poderá auxiliar na construção da racionalidade social, sendo uma resposta aos desafios concretos. ${ }^{71}$

A dogmática de direitos fundamentais se apoia, sobretudo, no racionalismo crítico, uma filosofia que tem como fundamento toda informação crítica que seja relevante frente ao sistema e que subtraia o ponto de vista do grau de desenvolvimento já alcançando, evitando qualquer tipo de vinculação a dogmas. Trata-se, portanto, de uma dogmática flexível, do tipo aberta, que busca ajudar a prática social de forma imediata, bem como possibilitar uma filosofia jurídica crítica e material, similar à sociedade aberta proposta por Karl Popper. ${ }^{72}$

Ao considerar a influência da teoria de Popper e a sua mescla com aspecto cultural realizado por Häberle, se o ponto de partida tomado é a tese da cultura como ciência, questões e resultados próprios (investigação cultural política) devem ser enfrentados, os quais, por seu turno, conferem profundidade particular aos valores constitucionais, profundidade que considera os planos normativo e sociológico. Isso, porque toda a hipótese que tenha por fundamento e ponto de partida a cultura como ciência conduz ao espaço de discussão dos valores constitucionais de base comparatista. ${ }^{73}$

O processo de continuidade constitucional - tendo o tempo como dimensão - pode ser analisado e explicado a partir de uma perspectiva científico-cultural, que combina aspectos sociológicos, ideológicos e normativos, a fim de possibilitar a abertura do sistema para o trabalho de especialistas em ciências jurídicas e outras áreas do conhecimento que se interessam pelo mesmo objeto cultural de análise. ${ }^{74}$

${ }^{71}$ HÄBERLE, Peter. Pluralismo y constitución: estudios de teoría constitucional de la sociedad abierta. Trad. Emilio Mikunda Franco. Madrid: Tecnos, 2002. p. 186-187.

${ }^{72}$ HÄBERLE, Peter. Pluralismo y constitución: estudios de teoría constitucional de la sociedad abierta. Trad. Emilio Mikunda Franco. Madrid: Tecnos, 2002. p. 188.

${ }^{73}$ HÄBERLE, Peter. Pluralismo y constitución: estudios de teoría constitucional de la sociedad abierta. Trad. Emilio Mikunda Franco. Madrid: Tecnos, 2002. p. 160.

${ }^{74}$ HÄBERLE, Peter. Teoría de la Constitución como ciencia de la cultura. Trad. Emilio Mikunda Franco. Madrid: Tecnos, 2000. p. 159.
Ao se efetuar a interpretação constitucional a partir da perspectiva científico-cultural, podem-se obter melhores fórmulas de compreensão na relação entre os textos jurídicos e seus respectivos contextos. Assim, todos os estudos resultantes de uma compreensão dos valores constitucionais a partir da ciência da cultura em nível comparado estão atualmente intensificando seus esforços interdisciplinares, para permitir uma nova leitura da dignidade humana com valores considerados comuns pelas diversas sociedades (povo, razão, liberdade, direito e realidade, ideologia e interesses econômicos), ${ }^{75} \mathrm{em}$ função de se considerar os objetivos comuns dos Estados Constitucionais aportados e conectados na (e pela) dignidade da pessoa humana. ${ }^{76}$

Entre os termos-chave que podem nominar a crescente riqueza formal e evolução mais recente dos textos constitucionais, estão dentro dessa tendência: (a) a evolução da competência puramente formal em face da tarefa substantiva; (b) a utilização deliberada de normas 
de reconhecimento, valores fundamentais e estruturais, ${ }^{77}$ junto com garantias de identidade, em diversos âmbitos e variantes (as cláusulas do espírito) e (c) a ampliação dos direitos fundamentais por meio de normas que estabelecem tarefas relacionadas com o seu conteúdo essencial. ${ }^{78}$

É papel da interpretação constitucional identificar as diferentes funções de uma norma constitucional, principalmente de um direito fundamental, a fim de se dar preferência à interpretação que desenvolva melhor a eficácia jurídica da norma em debate.

Desse modo, os direitos fundamentais assumem uma nova panorâmica a partir da tríade (a) dignidade humana e colocação do sujeito como centro do debate jurídico; (b) faceta participativa do sujeito pelo desenvolvimento do conteúdo democrático e (c) dimensão da igualdade de participação do sujeito, pelo desenvolvimento da sociedade aberta. ${ }^{79}$ Assim, não basta reconhecer e consagrar os direitos do homem, mas é preciso lhe fornecer garantias de pro-

\footnotetext{
77 A determinação de valores fundamentais/constitucionais de um ordenamento jurídico necessariamente não precisa estar vinculada a um texto constitucional, mas sim ser considerada uma "estrutura constituinte" do próprio sistema constitucional, a fim de compartilhar premissas e estruturas metodológicas com os outros sistemas jurídicos. Dessa forma, no campo econômico - com a competitividade pública, as leis antimonopólio e as linhas diretivas dos grupos econômicos -, a defesa do consumidor, as normas de proteção ao meio ambiente, a cultura política, a prática parlamentar, os juízos de políticos e a atuação da mídia, bem como os elementos do constitucionalismo que constituem uma sociedade positivamente estabelecida, como a dignidade humana, a democracia pluralista, a concretização dos direitos fundamentais, a capacidade postulatória de o sujeito buscar a concretização dos direitos fundamentais (status activus processualis), a harmonia e a interdependência das funções de Poder do Estado, a organização na forma de descentralização vertical do poder estatal (federalismo e regionalismo com a respectiva autonomia política), a independência da justiça constitucional. Enfim, esse pode ser considerado um rol exemplificativo do que seria compreendido como um valor constitucional/ fundamental, em termos de processo de constitucionalização e fertilização cruzada para a teoria da Internacionalização do Direito. Cf. HÄBERLE, Peter. Pluralismo y constitución: estudios de teoría constitucional de la sociedad abierta. Trad. Emilio Mikunda Franco. Madrid: Tecnos, 2002. p. 87-88; e Cf. HÄBERLE, Peter. Novos horizontes e novos desafios do constitucionalismo. Direito Público, Brasília, n. 13, p. 99-120, trimestral, 2006.

${ }^{78}$ HÄBERLE, Peter. El Estado Constitucional. México: Instituto de Investigações Jurídicas, UNAM, 2003. Disponível em: $<$ http://www.bibliojuridica.org/libros/libro.htm?l=14>. Acesso em: 26 jan. 2008. p. 109-110.

${ }^{79}$ HÄBERLE, Peter. Pluralismo y constitución: estudios de teoría constitucional de la sociedad abierta. Trad. Emilio Mikunda Franco. Madrid: Tecnos, 2002. p. 191.
}

teção que lhe devem estar associadas, que apenas regimes políticos que adotam o conteúdo democrático como fundamento estrutural podem oferecer em toda a plenitude. ${ }^{80}$

Há um sistema global de proteção bem diferenciado - que emana das construções teóricas e dos direitos fundamentais -, fazendo-o de tal forma que os sujeitos, a partir de sua autodeterminação conseguida pelo conteúdo essencial dos direitos fundamentais, devem ser "vigilantes ativos dentro da própria comunidade". ${ }^{81}$

\section{A responsabilidade de proteger à luz da relei- tura da soberania em matéria de direitos hu- manos: uma perspectiva dos valores constitu- cionais}

A Responsabilidade de Proteger é a nova nomenclatura utilizada para as intervenções humanitárias militares realizadas pela $\mathrm{ONU}$, não se denominando mais a terminação que definia o direito de "ingerência". A proposta da revigoração dessa nomenclatura está na ponderação que seu texto propõe: resguardar a soberania dos Estados ou combater a violação de direitos humanos?

A justa causa para a atuação da ONU na responsabilidade de proteger tem o foco central em evitar o cometimento de genocídio e de limpeza étnica. Por meio de operações multilaterais, realiza-se por meios proporcionais a última opção que é a intervenção militar.

Todavia, o direito internacional vive um movimento fragmentado, em que os valores da liberdade estão sendo rediscutidos por premissas com valores culturais diversos daqueles preenchidos pela comunidade dos Estados Europeus e Americanos. Este problema do multiculturalismo quando da intervenção humanitária revela a necessidade de regras claras para se proceder com legitimidade a intervenção militar.

Sobretudo a Líbia é o palco central da última ação do Conselho de Segurança em promover a proteção dos cidadãos líbios contra a atuação desenfreada do líder totalitário Muammar Gaddafi. Essa situação define bem a refor-

\footnotetext{
${ }^{80}$ BARRETO, Irineu Cabral. A Convenção europeia dos direitos do homem anotada. 3. ed. Coimbra: Coimbra Editora, 2005. p. 23.

${ }^{81}$ HÄBERLE, Peter. Pluralismo y constitución: estudios de teoría constitucional de la sociedad abierta. Trad. Emilio Mikunda Franco. Madrid: Tecnos, 2002. p. 219.
} 
mulação do conceito de soberania - agora visto como atributo da responsabilidade de proteger valores fundamentais -, que constitui a discussão central do direito internacional.

Com a responsabilidade de proteger, novos padrões de adoção dos direitos humanos - como a busca da efetividade - são reconhecidos pelos Estados que pertencem à ONU, com a possibilidade de efeito irradiante dos direitos humanos na conduta dos Estados no plano das relações internacionais.

O tema da Segurança nas Relações Internacionais e a responsabilidade de prevenir, de reparar e de reagir ressaltam a evolução da discussão, a ponto de se indagar se os caminhos e as premissas do Estado soberano devem permanecer incólumes diante das afrontas cometidas ao valor fundamental da dignidade da pessoa humana. A resposta parece ser que não.

A reconstrução da paz torna-se a pauta global dos países membros da ONU, que envolve um diálogo transdisciplinar, não apenas aqueles que estão imersos no combate e os refugiados e os repatriados, mas também outras nações e outras culturas, inclusive os ingressos na formulação do terror.

A justiça de transição é um dos instrumentos mais adequados para recompor e conferir nova energia e possibilidades de reconciliação entre os povos. Mas para que seja efetiva, é necessário observar os limites de ocupação estabelecidos pela cultura e se pautar pela proteção evolutiva dos direitos humanos.

Nesse contexto, a Soberania revela-se como a capacidade do Estado em formular a paz, com a responsabilidade de prevenir, reagir e reconstruir a vida dos povos, permitindo que gradualmente os direitos humanos ganhem corpo na racionalidade social e no multiculturalismo, promovendo a autodeterminação do indivíduo em matéria de direitos humanos, capaz de alcançar aquilo que Kant delimitou como a paz perpétua entre os povos: o respeito à diversidade e à essência do conteúdo essencial dos direitos e garantias das pessoas concernentes em harmonia com a estrutura institucional do Estado.

\section{Considerações Finais}

A responsabilidade de proteger exige que os direitos fundamentais e os direitos humanos se comportem como núcleos essenciais de irradiação de valores protetivos dos povos e dos indivíduos, consubstanciando-se no papel dos sistemas de proteção dos direitos humanos e na desenvoltura da emergência da proteção no plano do direito internacional.

Nesse sentido, adotando uma premissa metodológica de imputar a racionalidade social e a diversidade cultural na conformação do direito internacional, tornase necessário e imperioso que se tenha uma perspectiva evolutiva de alcance das Nações Unidas, no que toca ao conceito de responsabilidade de proteger.

A responsabilidade de proteger não deve ser considerada uma imposição cultural à imersão de diversidade de etnias e culturas existentes no globo. É sim um papel do direito internacional na luta contra a violação dos direitos humanos, mas deve exercitar ao máximo a vertente da proteção, com a reconstrução dos aspectos institucionais de desenvolvimento dos povos e regiões afetadas pela destruição, como também deve emergir com um caráter emancipatório, pois, estabelecendo que a soberania é a capacidade de se formular a paz, a concretização dessa medida se tornará efetiva levando o indivíduo, por meio do respeito à premissa do multiculturalismo e cuidando dos direitos humanos e dos direitos fundamentais na perspectiva da racionalidade crítica, a ter sua autodeterminação no espaço público de construção da dignidade e vida dos povos em sociedade.

\section{Referências}

ALEMANHA. Bundesverfassungsgericht. BVerfGE 7, 198 (207). Disponível em: <http://www.bverfg.de >. Acesso em: 26 jul. 2008.

BARRETO, Irineu Cabral. A Convenção europeia dos direitos do homem anotada. 3. ed. Coimbra: Coimbra Editora, 2005.

CANOTILHO, José Joaquim Gomes. Direito constitucional e teoria da Constituição. 7. ed. Coimbra: Almedina, 2003.

CORTE INTERAMERICANA DE DERECHOS HUMANOS. Caso comunidad indígena Yakye Axa vs. Paraguay. Sentencia de 17.6.2005 (Fondo, Reparacíones y Costas). Disponível em: <http://www.corteidh.or.cr/>. Acesso em: 22 out. 2008.

CRUZ, Luis M. La Constitución como orden de valores. Problemas jurídicos y políticos. Un estudio sobre los orígenes del neoconstitucionalismo. Colección filosofía, derecho y sociedad. Granada: Comares, 2005. 
EUROPEAN COURT OF HUMAN RIGHTS. Fourth Section. Salgueiro da Silva Mouta vs. Portugal (Application $n^{o}$ 33290/96), j. 21.12.1999. Disponível em: <http://www. echr.coe.int>. Acesso em: 27 jun. 2008.

EUROPEAN COURT OF HUMAN RIGHTS. Second Section. Moldovan and others vs. Romania (Applications $n^{\circ}(s)$ 41138/98 and 64320/01), j. 12.7.2005. Disponível em: <http://www.echr.coe.int/>. Acesso em: 25 set. 2008.

HÄBERLE, Peter. ElEstado Constitucional. México: Instituto de Investigações Jurídicas, UNAM, 2003. Disponível em: <http://www.bibliojuridica.org/libros/libro.htm?l=14>. Acesso em: 26 jan. 2008.

HÄBERLE, Peter. Estado Constitucional Cooperativo. Trad. Marcos Augusto Maliska e Elisete Antoniuk. Rio de Janeiro: Renovar, 2007.

HÄBERLE, Peter. La garantía del contenido esencial de los derechos fundamentales. Trad. Joaquín Brage Camazano. Madrid: Dykinson, 2003.

HÄBERLE, Peter. Libertad,igualdad, fraternidad: 1789 como historia, actualidad y futuro del Estado Constitucional. Trad. Ignacio Gutiérrez Gutiérrez. Madri: Minima Trotta, 1998.

HÄBERLE, Peter. Novos horizontes e novos desafios do constitucionalismo. Direito Público, Brasília, n. 13, p. 99120, trimestral, 2006.

HÄBERLE, Peter. Pluralismo y constitución: estudios de teoría constitucional de la sociedad abierta. Trad. Emilio Mikunda Franco. Madrid: Tecnos, 2002.

HÄBERLE, Peter. Teoría de la Constitución como ciencia de la cultura. Trad. Emilio Mikunda Franco. Madrid: Tecnos, 2000.

HALL, Stuart. A identidade cultural na pós-modernidade. 11. ed. Trad. Tomaz Tadeu da Silva e Guacira Lopes Louro. Rio de Janeiro: DP\&A, 2006.

INTERNATIONAL COMMISSION ON INTERVENTION AND STATE SOVEREIGNTY - ICISS. The Responsability to Protect: Report of the International Commission on Intervention and State Sovereignty. Ottawa: International Development Research Centre, 2001.

KOTZUR, Markus. La soberanía hoy. Palabras clave para un diálogo europeo-latinoamericano sobre un atributo del Estado constitucional moderno. In: HÄBERLE, Peter; KOTZUR, Markus. De la soberanía al derecho constitucional común: palabras clave para un diálogo europeo-latinoamericano. Trad. Héctor Fix-Fierro. México: Universidad Nacional Autónoma de México, Instituto de Investigaciones Jurídicas. 2003, p. 95. (Serie Ensayos Jurídicos, n. 12). Disponível em: <http://www.bibliojuridica. org/libros/ libro.htm?l=545>. Acesso em: 26 ago. 2007.
LIMA, José Antonio Farah Lopes de. Convenção europeia de direitos humanos. São Paulo: J. H. Mizuno, 2007.

MARTINS, Leonardo (Org.). Cinquenta anos de jurisprudência do Tribunal Constitucional Federal Alemão. Coletânea original: Jürgen Schwabe. Montevideo; Uruguay: Konrad-Adenauer-Stiftung, 2005.

PIOVESAN, Flávia. Direitos humanos e o direito constitucional internacional. 9. ed. rev. ampl. e atual. São Paulo: Saraiva, 2008.

ROCHA, Maria Elizabeth Guimarães Teixeira. Limitação dos mandatos legislativos: uma nova visão do contrato social. Porto Alegre: S. A. Fabris, 2002.

SANTOS, Boaventura de Sousa. Por uma concepção multicultural de direitos humanos. DHnet: Direitos humanos na internet, multiculturalismo e direitos humanos. Disponível em: <http://www.dhnet.org.br/ cultura/multiculturalismo/>. Acesso em: 5 out. 2008.

SIEYÈS, Emmanuel Joseph. A Constituinte Burguesa (Qu'est-ce que le Tiers Etat?). 4. ed. Rio de Janeiro: Lúmen Juris, 2001.

SILVA, Christine Oliveira Peter da. Como se lê a Constituição: abordagem metodológica da interpretação constitucional. Direito Público, Porto Alegre, v. 1, n. 6, p. 136-152, trimestral, 2004.

SILVA, Christine Oliveira Peter da. Estado constitucional cooperativo: o futuro do Estado e da Interpretação Constitucional sob a ótica da doutrina de Peter Häberle. Revista Jurídica, v. 7, n. 72. Disponível em: <https://www. planalto.gov.br/ccivil_03/revista/revistajuridica/index. htm>. Acesso em: 08 jun. 2008.

SILVA, Christine Oliveira Peter da. Tensões entre o direito constitucional e o direito internacional: uma necessária revisitação do conceito de Estado Soberano. In: CONGRESSO BRASILEIRO DE DIREITO INTERNACIONAL, 9., Curitiba. Anais... Curitiba: Juruá, 2011.

SOUSA, João Ramos de. Apresentação: ainda há juízes em Estrasburgo. Sub Judice: Justiça e sociedade. Direitos humanos no Tribunal Europeu, Lisboa, n. 28, abr./set. 2004.

ZAGREBELSKY, Gustavo. El derecho dúctil. Ley, derechos, justicia. Trad. Marina Gascón. 7. ed. Madrid: Trotta, 2007. 